\title{
Position of social sciences and humanities within the scientific disciplines and its measurement through CRIS system
}

\author{
Danica Zendulková, Boris Rysul'a and Andrea Putalová
}

Slovak Centre of Scientific and Technical Information, 81104 Bratislava, Slovakia

\begin{abstract}
The information system for research, development and innovation SK CRIS is the main tool for mapping Slovak science. The data on research were appropriate for the analysis at the time they were structured, on the national level, of high quality, consistency and covering as many components as possible and in mutual relations. The SK CRIS functionality brings the ability to offer aggregated information from these data and to present them according to various aspects. It is allowed by the implementation of the crucial standard for CRIS systems, supported by European Commission. Use of data format CERIF which mutual relations between objects and semantics allow record the objects with mutual ties.

Our ambition is to demonstrate the possibility of using the SK CRIS data. In the light of the increasing importance of the societal impact of research, this article attempts to address the question as to how Social Sciences and Humanities (SSH) research outputs from 2019 are represented in Slovak research portfolios. The analysis prompts the conclusion that Social Sciences and Humanities research outputs in Slovakia in 2019 are appropriately represented. This can be documented by the proportion represented by the SSH research projects and involved organisations and researchers.
\end{abstract}

\section{Introduction}

In the national portfolio of research activities, the social sciences and humanities (SSH) are often relegated to the sidelines. The priorities of national science policies are mainly focused on the natural and technical sciences. The priorities of the state science policy of Slovakia [1] do not deviate from the pan-European trend. The preferred scientific disciplines are as follows: materials research and nanotechnology, information and communication technologies, biotechnology and biomedicine, agriculture and the environment, sustainable energy and energy.

The claim is that the SSH are less strongly represented in the research portfolio than other scientific fields. We want to confirm this on the basis of data analysis of the information system on research, development and innovation SK CRIS [2] and by using the basic groups of R\&D fields according to the FRASCATI manual [3].

${ }^{1}$ Corresponding author: danica.zendulkova@cvtisr.sk 


\section{Background}

The possibility of analysing the share of social sciences and humanities in the research portfolio is conditioned by the meeting of three conditions. The basic starting point is the theory and methodology of research information processing, covered by the international organisation for research information euroCRIS [4]. The creation of a common European standard, the CERIF data format [5], which is being developed within the euroCRIS on the basis of the requirements of the European Commission was essential.

The second condition for the analysis is classification of available research information according to scientific disciplines. This classification is not directly defined by the CERIF format, but it is based on international recommendations and methodologies.

The third important condition is the existence of information system on research, development and innovation SK CRIS. This system has been built in accordance with international methodologies and standards and contains regularly collected data on research at the national level.

The SK CRIS data have served mainly to contribute to annual reports on research in Slovakia issued by the Ministry of Education, Science, Research and Sport. During the processing of data from 2019 [6], the basis for the selection of indicators and a proposal for the procedure developed as part of this research was created. It was tested and used for the first time on the example of data from the social sciences and humanities. [7]

\subsection{Processing of research information}

Theory and methodology of research information processing are concentrated about current research information system. A current research information system (CRIS) is a database or other information system to store, manage and exchange contextual metadata for the research activity funded by a research funder or conducted at a research-performing organisation [8]

CRIS systems are relatively powerful tools, supporting the mutual communication of the research community [9] and the formation of scientific policy [10]. They are intended for the large target group to which belong researchers, research managers, research strategists, publication editors, intermediaries and those responsible for technology transfer, as well as the media and public. CRIS are closely associated with the relational data format CERIF (Common European Research Information Format) [11], standard for managing and exchanging research data [12].

\subsection{Evidence of R\&D fields}

The code list of R\&D fields [13] in the sense of the FRASCATI manual [3] is a three-level code list, where the first level is identical with the basic fields according to the FRASCATI manual, the second level of the Slovak code list differs slightly from these fields in some items, but it is identical in the SSH categories. The third level of the code list specifies scientific disciplines on national level with higher granularity than FRASCATI manual.

The code list of R\&D fields is used to identify scientific disciplines of basic entities (projects, organisations, researchers) within the SK CRIS system. 


\subsection{Slovak Current Research Information System SKCRIS}

The Slovak Current Research Information System (SK CRIS) as a part of the Central Information Portal for Research, Development and Innovation (CIP RDI) has the status of Information system of public administration. The Slovak Centre of Scientific and Technical Information (SCSTI) is responsible for operating, maintaining and providing technical support to this system on behalf of the Ministry of Education, Science, Research and Sport of the Slovak Republic. The SKCRIS uses the data model CERIF 1.3 [14] and it has been put into operation in 2013.

The SK CRIS information system integrates data on research and development in Slovakia within the register of $R \& D$ organisations, the register of $R \& D$ projects, the register of researchers and the register of $R \& D$ results. Through the system, the process of assessment of competence to perform research and development is administered, as well as the additional statistical survey of the research and development potential of the Ministry. The SK CRIS information system at 4th April 2021 contained the following data:

21085 R\&D projects

483 calls for R\&D projects proposals

2435 R\&D organisations

34564 researchers

447391 R\&D results

The aims of operating SK CRIS are divided into four groups:

1. The presentation of information and new knowledge and its interchange between researchers in electronic environment

2. To support the implementation of knowledge into practice.

3. To obtain general support for science and research.

4. Publicity of science, research and their practical results by comprehensible way attractive for the public. [15]

CRIS system is an appropriate tool for determining the representation of individual scientific disciplines in R\&D only if it monitors data on research activity in all scientific fields at the national level. The SK CRIS system meets this condition.

\section{Data and its analysis}

As part of the analysis, we focused on research projects, research organisations and researchers. The results of the research (mainly publications) could not be processed in this way, as in SK CRIS we do not register a R\&D fields for research results. For analysis of research results by $R \& D$ fields any other data sources should be used (i.e. scientific databases Scopus and WoS).

We focused on SK CRIS data with regard to the share of basic groups of R\&D fields (first level of code list described in part 2.2).

\subsection{Register of projects}

Register of projects contains the information about the R\&D activities funded mainly by the state budget. These projects are funded by Slovak grant schema, mainly of the Slovak 
Research and Development Agency (SRDA); Scientific Grant Agency VEGA; Cultural and Educational Grant Agency KEGA; and the system of Incentives for Research and Development. The entry of these projects is carried out through the integration interface of SK CRIS based on API web services. The data flows directly from the systems of Slovak grant agencies.

The second category of projects contains international R\&D projects funded by several grant schema of European Commission, i.e. FP7, Horizon 2020, COST, etc. or by international research infrastructures. Some R\&D projects are also supported by regional programmes, mainly Visegrad Fund, Danube Strategy etc. Data about these projects are often entered to SK CRIS by responsible of R\&D organisations.

In contrast of data imported by Slovak grant agencies, data entered by SK CRIS users should be validated and completed in the process of data management by SK CRIS data curator. The long-term task of the data curator is to increase the quality and completeness of data on international projects.

Let us illustrate the share of projects by basic groups of R\&D fields in projects, the solution of which was implemented in 2019. We analysed the latest data. Data from 2020 will be available on the summer of 2021.

These were mostly multi-year projects that started in the observed year or earlier and at the same time their completion was planned either in 2019 or later.

In the monitored year, $4258 \mathrm{R} \& \mathrm{D}$ projects were solved. A total of 581 research organisations took part in solving them. It means, one organisation participates on average in more than 7,3 projects.

These organisations were involved in the solution of projects 6970 times, which means that several projects were solved in cooperation at least two organisations. One project was solved on average by 1.6 solving organisations.

The categorisation of projects by basic groups of $R \& D$ fields can be found in Table 1 . To clarify, not all projects have assigned R\&D fields. These are mainly wide-ranging multidisciplinary projects, funded by international grant schemes or the EU Structural Funds. SK CRIS currently allows to register only one R\&D field for one object. In some cases, it is not possible to easily identify this field. At that time, the R\&D field is not mentioned in the project record in the register.

The table shows that $18 \%$ of the total number of R\&D projects belongs to social sciences and $11 \%$ to the field of humanities. 
Table 1. Projects realized in 2019 by basic groups of R\&D fields

\begin{tabular}{|l|l|l|}
\hline $\begin{array}{l}\text { Projects } \\
\text { realized in } \\
\text { 2019 by basic } \\
\text { groups of } \\
\text { R\&D fields }\end{array}$ & No & Percentage \\
\hline $\begin{array}{l}\text { Natural } \\
\text { sciences }\end{array}$ & 1011 & $26 \%$ \\
\hline $\begin{array}{l}\text { Engineering } \\
\text { and technology }\end{array}$ & 995 & $26 \%$ \\
\hline $\begin{array}{l}\text { Medical and } \\
\text { health sciences }\end{array}$ & 393 & $10 \%$ \\
\hline $\begin{array}{l}\text { Agricultural } \\
\text { and veterinary } \\
\text { sciences }\end{array}$ & 313 & $8 \%$ \\
\hline Social sciences & 696 & $18 \%$ \\
\hline $\begin{array}{l}\text { Humanities } \\
\text { and the arts }\end{array}$ & 431 & $11 \%$ \\
\hline Total & 3839 & $100 \%$ \\
\hline
\end{tabular}

Source: SK CRIS database, 4th April 2021
Projects realized in 2019 by basic groups of R\&D fields

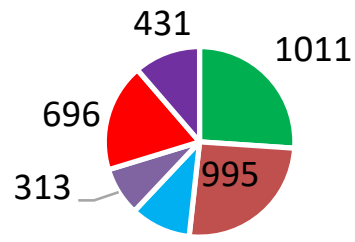

393

- Natural sciences

- Engineering and technology

- Medical and health sciences

- Agricultural and veterinary sciences

- Social sciences

- Humanities and the arts

\subsection{Register of organisations}

The register of $R \& D$ organisations contains basic data on research organisations realizing a research project, or have submitted an application form for the assessment of competence to perform $R \& D$, or they are $R \& D$ certificate holders. The database also contains other organisations whose declared focus on R\&D.

It means that the register contains various historical records of $R \& D$ organisations, as well as data on those R\&D organisations which, apart from registration in SK CRIS, did not declare any research activity. We will therefore focus on organisations - holders of certificates of competence to perform R\&D. These organisations form a subset of the register of organisations, their records are up to date (as of 31 December 2020) and they are usually high-quality, efficient and active research organisations.

The number of these organisations by R\&D fields can be found in table 2 . In Table 3 we can see the classification research organisations with $R \& D$ certificate and with SSH R\&D fields by R\&D sector.

The R\&D sector is important for us to identify which organisations are engaged in research. Among the organisations in Table 3, we find a relatively large number of universities. However, for the purpose of assessment of competence to perform R\&D the university is considered as a one unit. The university has assigned predominant scientific field.

It should be explained that in the register of organisations we register both the university and their faculties. Correct and precise assignment of R\&D fields is the reason of this form of evidence both university and faculties. Nevertheless, the faculty is not a legal body. But $R \& D$ projects are mostly assigned to the faculty (instead of the university). It means $R \& D$ fields of projects beneficiaries could be identified more precisely. 
Table 2. Organisations with R\&D certificate by basic groups of R\&D fields

\begin{tabular}{|l|r|r|}
\hline $\begin{array}{c}\text { Organisations } \\
\text { with R\&D } \\
\text { certificate by } \\
\text { basic groups of } \\
\text { R\&D fields }\end{array}$ & No & Percentage \\
\hline Natural sciences & 123 & $17 \%$ \\
\hline $\begin{array}{l}\text { Engineering and } \\
\text { technology }\end{array}$ & 443 & $59 \%$ \\
\hline $\begin{array}{l}\text { Medical and health } \\
\text { sciences }\end{array}$ & 58 & $8 \%$ \\
\hline $\begin{array}{l}\text { Agricultural and } \\
\text { veterinary sciences }\end{array}$ & 40 & $5 \%$ \\
\hline Social sciences & 54 & $7 \%$ \\
\hline $\begin{array}{l}\text { Humanities and the } \\
\text { arts }\end{array}$ & 29 & $4 \%$ \\
\hline Total & $\mathbf{7 4 8}$ & $100 \%$ \\
\hline
\end{tabular}

\section{Organizations with R\&D certificate by $R \& D$ fields}

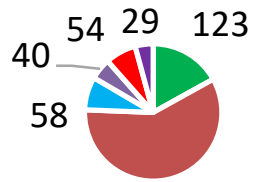

443

- Natural sciences

- Engineering and technology

- Medical and health sciences

- Agricultural and veterinary sciences

- Social sciences

- Humanities and the arts

Source: SK CRIS database, 31st December 2020

Table 3. Organisations with $R \& D$ certificate by $R \& D$ sector

\begin{tabular}{|c|c|}
\hline Organisations from Tab 2 by $R \& D$ sector & No \\
\hline Social sciences & 54 \\
\hline - $\quad$ universities & 16 \\
\hline - $\quad$ SAS institutes & 11 \\
\hline - $\quad$ state organisations & 8 \\
\hline - $\quad$ private organisations & 12 \\
\hline - non -profit organisations & 7 \\
\hline Humanities and the arts & 29 \\
\hline - $\quad$ universities & 6 \\
\hline - $\quad$ SAS institutes & 8 \\
\hline - $\quad$ state organisations & 13 \\
\hline - private organisations & 2 \\
\hline - non -profit organisations & 0 \\
\hline
\end{tabular}

Source: SK CRIS database, 31 st December 2020

On the Table 2 we can see only $7 \%$ of $R \& D$ organisations are engaged in social science research. $4 \%$ of organisations are dedicated to research in the humanities.

It can be stated that the SSH orientation in the higher education sector is probably slightly overestimated. As 22 out of 32 Slovak universities declare mostly a social science or humanities scientific profile. At the same time, all of these universities have faculties of various specializations, not only predominant ones.

If we considered the faculty as an independent body (like an university), share of SSH organisations in their total number would slightly decrease. 


\subsection{Projects and Organisations: who is involved to SSH projects}

The analysis shows that a relatively small number of organisations (social sciences:54 and humanities 29 organisations by Table 2) address a relatively higher share of SSH projects in the total number of projects (696 resp. 431 projects by Table 1 ).

We wondered why this condition occurred. There are two possible explanations. Namely that SSH organisations realized more than average number of projects, or organisations that declare another group of R\&D fields also deal with SSH projects.

If we divided these two numbers $(696+431 / 54+29)$, we receive 13,5 projects by organisation. But the organisations from the Table 2 are the R\&D certificate holders and may not be all involved to the projects in 2019.

Therefore, we examined how many projects are solved by the R\&D organisations, as well as which organisations participate in SSH projects. We were interested not only in the classification of organisations according to the scientific fields, but also according to the $R \& D$ sector. The reason for the classification by $R \& D$ sector is that we want to find out how other than the academic and state sector participates in research in the field of SSH. Private and non-profit organisations are is relatively weakly represented among research organisations dedicated to (not only) SSH.

As can be seen from Table 1, in 2019 a total of 1127 SSH projects were solved. With database tools in the MS SQL environment, we found that they were solved by a total of 186 organisations (including faculties and similar organisational units of universities). It means, one organisation participates on average in 6 projects.

These organisations were involved in the solution of projects 1942 times, which means that several projects were solved in cooperation at least two organisations and one project was solved on average by 1.7 solving organisations.

An overview of the number of SSH project solvers by R\&D sector and their involvement in projects can be found in Table 4 .

Table 4. Organisations by R\&D sector and projects involvement

\begin{tabular}{|l|l|l|l|l|}
\hline $\begin{array}{c}\text { Projects solving } \\
\text { organisations- } \\
\text { sector }\end{array}$ & $\begin{array}{c}\text { Projects solving } \\
\text { organisations - } \\
\text { No }\end{array}$ & $\begin{array}{c}\text { Organisations } \\
\text { - percentage }\end{array}$ & $\begin{array}{c}\text { Number of involvements } \\
\text { of research organisations } \\
\text { in projects }\end{array}$ & $\begin{array}{c}\text { Percentage of } \\
\text { projects } \\
\text { involvement }\end{array}$ \\
\hline universities & 123 & $66 \%$ & 1629 & $84 \%$ \\
\hline SAS institutes & 29 & $16 \%$ & 267 & $14 \%$ \\
\hline $\begin{array}{l}\text { state } \\
\text { organisations }\end{array}$ & 17 & $9 \%$ & 27 & $1 \%$ \\
\hline $\begin{array}{l}\text { private } \\
\text { organisations }\end{array}$ & 10 & $5 \%$ & 11 & $0,5 \%$ \\
\hline $\begin{array}{l}\text { non -profit } \\
\text { organisations }\end{array}$ & 7 & $4 \%$ & 8 & $0,5 \%$ \\
\hline TOTAL & 186 & $100 \%$ & 1942 & $100 \%$ \\
\hline
\end{tabular}

Source: SK CRIS database, 4th April 2021 
Subsequently, we were interested in how many organisations solve projects in accordance with their research profile. The Table 5 shows that of the 186 involved organisations, 131 has SSH profile and 55 are other than SSH profile. It means, $30 \%$ of involved organisations have other than SSH profile. These organisations have been involved in SSH projects 256 times, which is $13 \%$ of participations in SSH projects solved in 2019.

Table 5. Organisations by R\&D sector, R\&D field and projects involvement

\begin{tabular}{|l|l|l|l|l|}
\hline $\begin{array}{c}\text { Project solving } \\
\text { organisations- } \\
\text { sector }\end{array}$ & $\begin{array}{c}\text { Project solving } \\
\text { SSH } \\
\text { organisations - } \\
\text { No }\end{array}$ & $\begin{array}{c}\text { Number of } \\
\text { project } \\
\text { involvement }\end{array}$ & $\begin{array}{c}\text { Project solving } \\
\text { not SSH } \\
\text { organisations - } \\
\text { No }\end{array}$ & $\begin{array}{c}\text { Number of } \\
\text { project } \\
\text { involvement }\end{array}$ \\
\hline universities & 87 & 1398 & 36 & 231 \\
\hline SAS institutes & 21 & 255 & 8 & 12 \\
\hline $\begin{array}{l}\text { state } \\
\text { organisations }\end{array}$ & 10 & 18 & 7 & 9 \\
\hline $\begin{array}{l}\text { private } \\
\text { organisations }\end{array}$ & 7 & 8 & 3 & 3 \\
\hline $\begin{array}{l}\text { non -profit } \\
\text { organisations }\end{array}$ & 6 & 7 & 1 & 256 \\
\hline TOTAL & 131 & 1686 & 55 & 1 \\
\hline
\end{tabular}

Source: SK CRIS database, 4th April 2021

As can be seen from tables no. 4 and 5, universities (their faculties) are the most active solvers of research projects.

Most projects in 2019 were solved by the Faculty of Arts of Comenius University, namely 106. The most active institute of the SAS was located in 8th place by SSH projects activity in 2019. It was the Historical Institute of the SAS, which in 2019 participated in 43 projects. Of the organisations whose research profile is not SSH, most projects were solved by the University of Žilina in Žilina, Faculty of Operation and Economics of Transport and Communications, which participated in 26 SSH projects in 2019.

\subsection{Register of researchers}

The register of researchers contains records of researchers, but also of support and administrative staff and staff of scientific and technical services for the entire period of building the database.

Non-research staff do not enter the field of science and technology on registration. Therefore, in table 6 the number of researchers by groups of R\&D fields does not correspond to the total number of registered researchers in the register.

The Table 6 shows almost $24 \%$ of researchers are involved in social sciences and $12 \%$ in the humanities representing a total of 8432 individuals.

In 2019, 3584 out of 8432 researchers declaring activity in the SSH scientific fields took part in projects teams. The number of researchers who participated in projects teams in 2019 is 4865 researchers. This difference of almost 1300 people includes experts who work outside the social sciences and humanities. 
Table 6. Researchers by basic groups of R\&D fields

\begin{tabular}{|l|r|r|}
\hline $\begin{array}{l}\text { Researchers by } \\
\text { basic groups of } \\
\text { R\&D fields }\end{array}$ & No & Percentage \\
\hline Natural sciences & 4594 & $19 \%$ \\
\hline $\begin{array}{l}\text { Engineering and } \\
\text { technology }\end{array}$ & 6208 & $26 \%$ \\
\hline $\begin{array}{l}\text { Medical and } \\
\text { health sciences }\end{array}$ & 2895 & $12 \%$ \\
\hline $\begin{array}{l}\text { Agricultural and } \\
\text { veterinary } \\
\text { sciences }\end{array}$ & 1633 & $7 \%$ \\
\hline Social sciences & 5595 & $24 \%$ \\
\hline $\begin{array}{l}\text { Humanities and } \\
\text { the arts }\end{array}$ & 2837 & $12 \%$ \\
\hline Total & 23762 & $\mathbf{1 0 0 \%}$ \\
\hline
\end{tabular}

Source: SK CRIS database, 4th April 2021

\section{Researchers by R\&D fields}

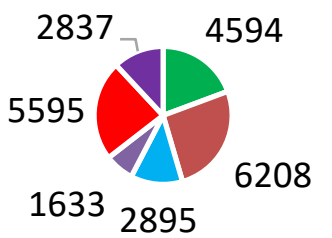

- Natural sciences

- Engineering and technology

- Medical and health sciences

- Agricultural and veterinary sciences

- Social sciences

- Humanities and the arts

\section{Summary}

The analysis showed that in 2019, 1127 projects in the SSH were solved, which is $29 \%$ of the total number of realized projects. Therefore, it cannot be stated that the SSH play marginal role in R\&D activities in 2019. But the share of SSH organisations on all R\&D organisations is only $11 \%$.

It means the relatively small number of SSH profiled organisations and on the other side, relatively higher share of SSH projects in the total number of projects. We considered two possible explanations, namely that SSH organisations realized more than average number of projects, or organisations that declare another group of R\&D fields also deal with SSH projects.

It is because we analysed which organisations participated in SSH projects. We state that 186 R\&D organisations participate on SSH projects, which is $32 \%$ of all organisations involved to $R \& D$ projects in 2019 . When $32 \%$ organisations are involved to $29 \%$ projects, the share is proportional.

But the analysis also shows that $30 \%$ of organisations involved to the SSH projects have other than SSH research profile. These organisations participated on $13 \%$ of SSH projects.

We summarise involvement to SSH projects is not just a domain of SSH profiled organisations. It is nothing new that project solutions require multidisciplinary cooperation. Finally, we see a strong societal impact in the challenges for all R\&D disciplines.

\section{References:}

1. Poznatkami k prosperite - Stratégia výskumu a inovácií pre inteligentnú špecializáciu Slovenskej republiky. 2013, [Online]. [cit. 4.4.2021] Available from: https://www.opvai.sk/media/98825/poznatkami-k-prosperite-stratégia-výskumu-ainovácií-pre-inteligentnú-špecializáciu-sr.pdf 
2. Slovak Current Research Information System (SK CRIS), [Online]. [cit. 4.4.2021] Available from: https://www.skcris.sk

3. Frascati manual. Guidelines for collecting and reporting data on research and experimental development. 2015, [Online]. [cit. 4.4.2021] Available from: https://www.oecd.org/sti/inno/Frascati-Manual.htm

4. EuroCRIS. What is euroCRIS? [Online]. [cit. 4.4.2021] Available from: https://www.eurocris.org/what-eurocris

5. About Common European Research Information Format. [Online]. [cit. 4.4.2021] Available from: https://joinup.ec.europa.eu/collection/eu-semantic-interoperabilitycatalogue/solution/common-european-research-information-format/about

6. Správa o Stave Výskumu a Vývoja v Slovenskej Republike a jeho Porovnanie so Zahraničím za rok. 2019. [Online]. [cit. 4.4.2021] Available from: https://rokovania.gov.sk/RVL/Material/25604/1

7. Zendulková, D.; Rysul'a, B.; Putalová, A. Representation of Slovak Research Information (A Case Study). Information 2021, 12, 137. https://doi.org/10.3390/info12030137

8. EuroCRIS. Why does one need a CRIS? [Online]. [cit. 4.4.2021] Available from: https://www.eurocris.org/why-does-one-need-cris

9. Fina, F.; Proven, J. Using a CRIS to support communication of research: Mapping the publication cycle to deposit workflows for data and publications. Procedia Comput. Sci. 2017, 106, 232-238, doi:10.1016/j.procs.2017.03.020.

10. Biesenbender, S.; Petersohn, S.; Thiedig, C. Using Current Research Information Systems (CRIS) to showcase national and institutional research (potential): Research information systems in the context of Open Science. Procedia Comput. Sci. 2019, 146, 142-155, doi:10.1016/j.procs.2019.01.089.

11. Pinto Sousa, C.; Simões, C.; Amaral, L. CERIF-Is the Standard Helping to Improve CRIS? Procedia Comput. Sci. 2014, 33, 80-85, doi:10.1016/j.procs.2014.06.013.

12. Lee, D.J.; Stvilia, B.; Wu, S. Toward a metadata model for research information management systems. Library Hi Tech 2018, 38, 577-592, doi:10.1108/LHT-01-20180013.

13. Číselník odborov vedy a techniky. [Online]. [cit. 4.4.2021] Available from: https://www.vedatechnika.sk/SK/VedaATechnikaVSR/odboryVaT/Stranky/default.asp $\underline{x}$

14. Jörg, B. et all. CERIF 1.3 Full Data Model (FDM): Introduction and Specification. [Online]. [cit. 4.4.2021] Available from: https://www.researchgate.net/publication/251880233_CERIF_13_Full_Data_Model_F DM_Introduction_and_Specification

15. Turn̆a, J. et al. (2012). The system SK CRIS, scientific publications and theses - mirror of Slovak science. In Proceedings of the 11th International Conference on Current Research Information Systems (June 6-9, 2012, Prague, Czech Republic). [Online]. [cit. 4.4.2021] Available from: http://dspacecris.eurocris.org/handle/11366/111. 